TITLE:

\title{
Prefrontal unit activity during visually guided lever pressing reaction in the monkey( Abstract_要旨)
}

\section{$\operatorname{AUTHOR(S):~}$}

Sakai, Masaki

\section{CITATION:}

Sakai, Masaki. Prefrontal unit activity during visually guided lever pressing reaction in the monkey. 京都大学, 1974, 理学博士

\section{ISSUE DATE:}

\section{4-03-23}

URL:

http://hdl.handle.net/2433/220329

RIGHT: 


\section{【59 】}

氏 名

学位の種 類 学位記 番号 学位授与の日付 学位授与の要件 研究科・専攻 学位論文題目

祮主查)
酒型正樹

理 学 博士

理 博 第 324 号

昭和 49 年 3 月 23 日

学位規則第 5 条第 1 項該当

理学研究科動物学専攻

\section{Prefrontal unit activity during visually guided lever} pressing reaction in the monkey

(サルの視覚刺激による単純テコ押し反応時に扔ける前頭前野の ニューロン活動)

教 授 久保田 競教授加藤幹太教 授池田次郎

\section{論文内容 の 要旨}

本実験はいわゆる短期記憶を含まない此較的単純な反応条件，即ちサルが光の手掛り刺激に誘道されて 行うテコ押し反応時に扔ける前頭前野のニューロン活動が視覚刺激受容と運動発現のいずれの側面に関与 するかを明らかにすることを意図して行われた。アカゲザルの前面のパネル上の 4 つの異った位置にラン プーテコの詨を置き，サルがスタートキーを押して 3 秒間待機するといずれか 1 つのランプをつけ，サル がそのランプ直下のテコを 1 秒以内に押した時報償として少量のジュースを与えた。他にテコ押しをさせ ないで光刺激だけを与えるテストと，光刺激を与えないでテコ押しだけを行わせるテストも同時に行ない，

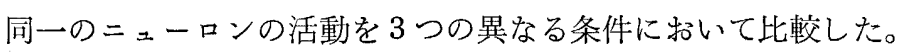

微少電極法を用いて同部から本反応に関与すると思われる約 90 ケの単一細胞活動を記録した。このうろ 半数は光一テコ押し時にスパイクの発射頻度の減少を, 残りは増加を示した。また，これらのうち上記 2 つのテストにより後者のうちには光刺激に応じずテコ押し時にのみ活動するものが $18 \%$ 激に応じ，かつ光刺激に続いてテコ押しが行なわれた場合にはスパイク頻度の顕著な增加が見られた。こ れは光刺激なしのテコ押し時, 及び報償と結びついているパネル上の 4 つのランプ以外のランプによる光 呈示時には活動しなかった。つまりこのニューロンはサルにとって意味をもつ視覚刺激受容を行うと同時 に受けた刺激に従って運動を遂行する時にはより著明に活動する。

また，全体の $30 \%$ \%ニーロンに颃いてはサルの待機中にすでにスパイク頻度の増加がみられたが，こ れといわゆる“期待波”と呼ばれる皮質表面陰性電位変動との関連を指摘した。

\section{論文審査の結果の要旨}

前頭葉の連合皮質（前頭前野）のニューロン活動が行動のコントロールに関与しているとする証拠は脳 の破壞実験，集合電位としての脳波活動の記録から得られたものでめって，直接単一ニューロン活動を記 録して行動との対応を調べた研究は1971年までなかった。前頭前野が関与する行動として遅延反応，遅延 
交代反応が知られているが,この反応時に同部のニューロン活動に变化のあったことが1971年に報告され ている。

申請者は最近の報告に導かれて遅延反応といった短期記憶を含む複雑な行動をはなれて，ょり単純な反 応一光がつくとテコを押す一時の前頭前野の背外側部で主溝の外側壁の尾側半分（ブロードマンの 8,9 , 10野を含む）の場所で単純テコ押し反応と関係のある90ケのニューロン活動を細胞外記録の方法で記録し た。このうち $1 / 3$ のもの光が呈示されると数十乃至数百ミリ秒でスパイク発射頻度を増し，テコ押しの開 始直前に最大となり，その効果はテコ押しの終了前後まで持続した。頻度の增加はサルがテコ押しを出来 ないようにし，光刺激のみを与えた場合著しく減少した。また，光刺激を与えないでテコ押しを行わせた 場合には著名な頻度の増加は認められなかった。この事実は前頭前野の一群のニニーロンは手掛りとなる 光刺激に反応するが, 同時にある特定の報償を与えられる行動を行う場合に引き金として働いており，こ れはテコ押しといった上腕による随意運動を行う時の運動野で見られる一群のニューロンのように常に特 定筋肉の収縮の引き金，及びそれの持続としてだけ働いているのではないことを明確にしたものである。 この事実は前頭前野が単なる運動のコントロールよりもより上位にある構造であることと対応するもので,

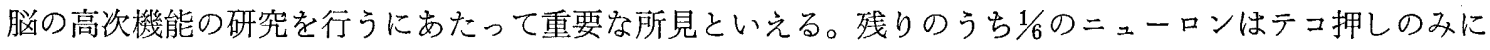
関連して，この運動が行われたあと頻度の増加を示したので運動の状態を前頭前野に伝えるための情報と しての意味があると考えた。また，記録された全体の約 $1 / 2$ のニューロンは光刺激ーテコ押し時に頻度を減 少した。変化の開始は正確には決められなかったが 2 次的な変化と考えられる。

さらに申請者の興味ある知見として光ーテコ押し行動を行う前に予期的に活動するニューロン全体の $1 / 3$ で認めて扣り，そのような活動を細胞レベルで始めて記述した。

本論文は脳の高次機能についての新知見であり, 神経生理学の分野で研究する場合の実例を示したもの で, 今後この方面での研究に大きく貢献するものである。参考論文 2 編は申請者にとって本論のための子 備的なものであって，これらの研究に参加することにより申請者は研究の進め方を着実に学びとった。

よって, 本論文は理学博士の学位論文として価值あるものと認める。 